\title{
MAJAS METAFORA DALAM PEMBERITAAN OLAHRAGA DI MEDIA MASSA CETAK
}

\author{
Ririen Ekoyanantiasih \\ Badan Pengembangan dan Pembinaan Bahasa \\ Email: ririen_suladi@yahoo.co.id \\ HP: 081385081280
}

\begin{abstract}
ABSTRAK
Penelitian ini bertujuan mendeskripsikan pemakaian majas metafora dalam ragam jurnalistik di pemberitaan olahraga. Dengan metode deskriptif, penelitian ini memaparkan majas-majas tersebut yang mengandung perbandingan antara dua hal. Hal pertama mengacu pada objek yang mempunyai makna murni dan hal kedua adalah makna kata yang sesuai dengan ciri-ciri kodrati suatu kata yang ditandai oleh fitur-fitur semantik.

Hasil penelitian menunjukkan bahwa di dalam media massa cetak ditemukan berbagai macam bentuk majas metafora, yaitu majas metafora dalam bentuk kata, frasa, dan klausa.
\end{abstract}

Kata kunci: denotasi, konotasi, majas, metafora

\section{ABSTRACT}

This research has a purpose to describe how to use methaphora figure of speech in journalism sport news. With descriptive method, the research explain some figure of speech which contain a comparison between two matter. The first matter refers to an object which has pure sense and second matter is the meaning of a word that appropriate with the characteristic of the anothor word which signed by semantic characteristic. This research showing that the printed mass media has found many kind of methaphora figure of speech, like methaphora figure in word, phrase, and clausa.

Key word: denotation; connotation, figure of speech, methaphora

\section{PENDAHULUAN}

Bahasa sebagai sarana komunikasi merupakan media untuk menyampaikan informasi di antara pembicara dan lawan bicara serta penulis dan pembaca. Dalam penyampaikan informasi tersebut, adakalanya seorang pembicara tidak mengerti makna kata yang diucapkan oleh lawan bicaranya. Hal tersebut dapat terjadi mengingat di samping adanya faktor-faktor di luar kebahasaan, seperti faktor usia dan jenis kelamin pembicara, juga ada faktor kebahasaan, misalnya makna lain atau makna tidak langsung yang disandang oleh kata tersebut. Pernyataan itu dapat diartikan bahwa makna di dalam pilihan kata memegang peranan penting karena bentuk kata yang sama mempunyai makna yang berbeda di dalam konteks kalimatnya.

Satu kata dapat memiliki makna denotatif saja atau memiliki makna konotatif. Makna denotatif adalah makna yang mempunyai arti tunggal, lugas, makna yang mengacu pada objek langsung (Pateda, 1987:67), misalnya, kata rumah mengandung makna denotatif 'sejenis bangunan yang mempunyai atap, pintu, dan jendela'. Makna denotatif tersebut sama dengan arti harfiah dan tidak ditafsirkan hubungannya dengan benda lain. Lain halnya dengan makna konotatif, makna tersebut muncul sebagai akibat asosiatif perasaan kita terhadap apa yang diucapkan atau didengar (Djajasudarma, 1993: 9).

Pada umumnya, makna konotasi dapat bersifat pribadi dan bergantung pada pengalaman orang seorang dengan kata atau dengan barang atau gagasan yang diacu oleh kata itu (Moeliono, 1989:173), misalnya, jika kata rumah mendapat prefiks di- dan sufiks kan, bentukan katanya menjadi dirumahkan. Kata berimbuhan dirumahkan mempunyai makna konotatif. Dengan adanya tambahan pengalaman pribadi, pengembangan imajinasi, dan kemampuan interpretasi pembaca, kata dirumahkan dapat mempunyai nilai rasa tambah. 
Kata tersebut dapat mempunyai makna lain atau makna tidak langsung, yaitu 'dipenjara' atau ' diberhentikan dari pekerjaan'.

Berkaitan dengan pernyataan tersebut di atas, pada umumnya makna konotatif lebih banyak jumpai dalam bentuk kiasan atau majas. Menurut Luxemburg (1984:187), makna kiasan atau majas memperlihatkan gejala bahwa suatu arti tertentu dialihkan kepada suatu hal lain sehingga timbul suatu arti yang baru. Pengertian yang satu dipergunakan dalam arti lain dan dibandingkan dengan yang pertama. Pertalian arti itu dapat terjadi apabila apa yang dikatakan dan apa yang sebetulnya dimaksudkan dapat dikaitkan satu dengan yang lain. Sehubungan dengan hal tersebut, majas atau makna kiasan tidak hanya digunakan dalam puisi-yang pemakaiannya dapat menimbulkan citraan dan imajinasi pembaca - tetapi juga digunakan dalam bidang lain seperti jurnalistik, baik dalam media massa cetak maupun elektronik.

Dalam surat kabar yang merupakan salah satu bentuk media massa cetak, pemakaian makna kiasan tersebut tampak jelas terlihat. Bahkan, untuk lebih menarik perhatian pembaca, judul-judul pemberitaannya ditulis dengan huruf kapital, seperti MAUNG BANDUNG, TIM AYAM JANTAN DARI TIMUR, AYAM KINANTAN DARI MEDAN. Contoh lainnya Butler Redam James, Arsenal Memikul Beban Berat.

Jika menyimak penggunaan kata-kata yang mengandung makna tidak langsung, memang terasa mampu mendorong indera pembaca untuk cepat menangkap maksud ungkapan atau kata tersebut. Hal itu disebabkan oleh karena majas relatif lebih sering konkret mengungkapkan makna daripada ungkapan harfiah (Djajasudarma, 1993: 20).

Sejalan dengan uraian tersebut, masalah utama penelitian ini adalah bagaimana bentuk dan makna majas metafora dalam ragam jurnalistik. Dengan demikian, tujuan penelitian ini adalah mendeskripsikan bentuk majas metafora dan makna majas metafora yang terdapat dalam bahasa Indonesia ragam jurnalisitik.

Penelitian ini dilakukan dengan menggunakan data kebahasaan tertulis. Sumber data yang digunakan adalah surat kabar terbitan Indonesia sebagai pemercontohnya. Percontoh surat kabar ditentukan dengan dasar pertimbangan surat kabar harian, terbitan Jakarta, memiliki jumlah oplah yang besar, jangkauan sasaran pembacanya yang luas, dan menganggap surat kabar 'baik' menurut penelitian masyarakat (Lumintaintang, 1992: 1). Dengan dasar pertimbangan tersebut, dipilih surat kabar Kompas, Media Indonesia, Republika, dan Warta Kota.

Selanjutnya, dari segi isi berita, pemakaian bahasa Indonesia ragam Jurnalisitk dengan topik olahraga digunakan sebagai bahan analisis data. Pemilihan topik berita tersebut perlu diperhatikan karena menurut pendapat Mackey (1970: 557) bahwa perbedaan pemilihan bahasa disebabkan oleh fungsi yang disandang oleh masing-masing bahasa, yaitu bahasa apa yang lebih tepat digunakan untuk menyampaikan maksud tertentu. Selain itu, pemilihan topik tersebut dilakukan dengan dasar asumsi bahwa di dalamnya banyak ditemukan penggunaan majas.

\section{Pilihan Kata}

Dengan bahasa orang akan menyampaikan ide atau gagasan yang dimaksud, baik secara lisan maupun secara tertulis. Demikian pula halnya yang dilakukan oleh para jurnalis, mereka menyampaikan ide atau gagasannya ke dalam pemberitaan lewat bahasa. Agar pembaca mengerti isi maksud atau gagasan tersebut, biasanya pembicara akan menggunakan dan memilih kata-kata yang sesuai dengan topik pembicaraan (Mackey, 1970: 557) atau memilih kata-kata yang mudah dipahami.

Berkaitan dengan hal tersebut, masalah pilihan kata memegang peranan yang penting di dalam komunikasi. Hal yang harus diperhatikan dalam menentukan pilihan kata adalah 
makna karena bentuk kata yang sama dapat bermakna lain di dalam konteks yang berbeda (Keraf, 1991: 24). Contoh kalimat berikut diambil dari surat kabar Kompas yang dapat memperlihatkan bahwa makna memegang peranan yang penting di dalam konteks kalimatnya.

1. Semi finalis Piala Cup Winners Parma menelan pil pahit di hadapan sekitar dua puluh tiga ribu pendukung fanatiknya.

2. Di samping harus menjalani diet yang teratur, pasien itu juga harus menelan pil pahit.

Makna kata menelan pil pahit pada kalimat 1 berbeda dengan kalimat 2. Di dalam kalimat 1 kata menelan mengandung makna konotasi yang bermakna 'mengalami kekalahan'. Sementara itu, di dalam kalimat 2 ungkapan menelan pil pahit mengandung makna denotatif, yaitu 'memasukkan obat ke dalam mulut'.

Uraian tersebut membuktikan bahwa pilihan kata sangat penting dalam menentukan makna suatu kalimat. Berkaitan dengan hal tersebut, di dalam menentukan pilihan kata dituntut adanya kemampuan yang dapat membedakan nuansa-nuansa makna yang tepat dari gagasan atau ide. Kemudian, mempunyai kemampuan untuk menentukan bentuk pilihan kata yang sesuai dengan nilai rasa dan situasi pembaca atau lawan bicara (Keraf, 1991: 24).

Paparan tersebut berkaitan dengan pendapat Alwi et al. (1992:1 1) yang menyatakan bahwa diksi atau pilihan kata harus berdasarkan tiga tolok ukur, yaitu ketepatan, kebenaran, dan kelaziman. Yang dimaksud dengan kata yang tepat adalah kata yang mempunyai makna yang dapat mengungkapkan atau sesuai dengan gagasan pemakai bahasa. Kata yang benar adalah kata yang diucapkan atau ditulis sesuai dengan bentuk yang benar, baik kata dengan bentuk dasar maupun bentuk jadian. Kemudian, kata yang lazim diterangkan sebagai kata yang biasa digunakan untuk mengungkapkan gagasan tertentu.

\section{Makna Kata}

Kemampuan menentukan pilihan kata yang tepat dan sesuai dengan nuansa-nuansa makna suatu kata dapat memudahkan seseorang memahami ide atau gagasan yang dimaksud. Suatu kata mempunyai makna harfiah dan makna konotasi. Makna harfiah atau makna denotasi adalah makna langsung, makna yang mempunyai arti tunggal (Pateda, 2010). Sementara itu, Keraf (1991: 27) mengatakan bahwa suatu kata yang tidak mengandung makna tambahan atau perasaan-perasaan tertentu disebut dengan kata denotatif. Makna kata yang dikandungnya disebut dengan makna denotatif.

Berdasarkan kedua pandangan tersebut, makna denotatif atau makna harfiah di dalam penelitian ini adalah makna yang mempunyai arti tunggal. Makna yang mengacu pada objek tunggal dan makna yang tidak mempunyai nilai rasa tertentu. Di dalam penelitian ini, makna harfiah itu dapat diketahui lewat bantuan kamus, yaitu Kamus Besar Bahasa Indonesia (KBBI, 2008).

Selanjutnya, makna konotasi menurut Keraf (1991: 26) adalah makna kata yang mengandung arti tambahan, perasaan-perasaan tertentu dan nilai rasa tertentu pula. Sementara itu, Djayasudarma (1994: 9) mengatakan bahwa makna konotasi muncul sebagai akibat asosiatif perasaan kita terhadap apa yang diucapkan atau didengar. Di dalam konteks kalimatnya, makna harfiah suatu kata dapat berubah menjadi makna konotasi (Alwi et al., 1992: 2). Oleh karena itu, makna konotasi tersebut banyak dijumpai di dalam bentuk kiasan atau majas.

Di samping mengandung makna denotasi dan makna konotasi, tiap kata juga mengandung fitur-fitur semantik yang secara universal melekat pada kata tersebut. Fitur-fitur semantik itu merupakan ciri-ciri kodrati dari suatu kata (benda). Penyimpanan dari sifat-sifat kodrati suatu benda akan menimbulkan keganjilan (Alwi, et al., 2008: 240). 


\section{Majas Metafora}

Batasan majas yang diberikan Kamus Besar Bahasa Indonesia (2008) adalah cara melukiskan sesuatu dengan jalan menyamakan dengan sesuatu yang lain. Kemudian, Ensiklopedi Nasional Indonesia (1990:49) memberi batasan majas sebagai bahasa kiasan yang melukiskan sesuatu dengan membandingkannya dengan sesuatu yang lain, atau dengan sesuatu dan mempertautkannya dengan sesuatu yang lain.

Keraf (1991: 129) memakai istilah gaya bahasa kiasan untuk mengacu pada majas. Gaya bahasa Kiasan tersebut merupakan penyimpangan makna (figurafive of speech) yang dibentuk berdasarkan perbandingan atau persamaan. Menurut Keraf, membandingkan sesuatu dengan sesuatu yang lain berarti mencoba menemukan ciri-ciri yang menunjukkan kesamaan di antara dua hal.

Menurut Keraf (1991: 138), majas metafora adalah semacam analogi yang membandingkan dua hal, tetapi dalam bentuk yang sangat singkat dengan menghilangkan kata-kata, seperti: bagaikan, seperti, dan laksana. Lebih lanjut, Keraf (1991: 139) menjelaskan bahwa bagian pokok pertama langsung dihubungkan dengan bagian pokok kedua sehingga metafora tidak menyatakan suatu perbandingan secara terbuka atau secara eksplisit, tetapi sekedar memberikan sugesti adanya suatu perbandingan. Keraf menjelaskan bahwa arti yang lengkap dari suatu metafora bergantung pada konteksnya. Walaupun demikian, matafora itu dapat berdiri sendiri sebagai kata kerja, kata sifat, kata benda, frasa atau klausa.

\section{METODE PENELITIAN}

Penelitian ini dilaksanakan dengan menggunakan metode deskripstif. Sudayanto (1986: 62) mengatakan bahwa penelitian deskriptif adalah penelitian yang dilakukan berdasarkan fakta yang ada dalam kenyataan. Dengan demikian, dapat dikatakan bahwa hasil penelitian berupa perian bahasa seperti apa adanya dan tidak dibuat-buat.

Metode deskriptif tersebut ditunjang dengan teknik pengumpulan data dan teknis analisis data. Pengumpulan data dilaksanakan dengan melakukan pengamatan langsung terhadap objek penelitian, yaitu media massa cetak, surat kabar, terbitan Jakarta. Kemudian, data berupa berbagai majas metafora dikumpulkan dan dicatat. Data yang berhasil dikumpulkan itu dianalisis berdasarkan kerangka teori.

\section{Pemakaian Majas dalam Konteks Pemberitaan Olahraga}

Dalam pemberitaan olahraga di media massa cetak banyak ditemukan majas, terutama majas metafora. Hasil penelitian menemukan bahwa terdapat berbagai macam bentuk majas metafora, yaitu dalam bentuk kata, frasa, dan klausa. Majas-majas metafora tersebut dapat diklasifikasikan berdasarkan kelas katanya. Dalam temuan penelitian ini, pada umumnya majas metafora ditemukan dalam kelas kata nomina dan verba. Berikut di bawah ini diperlihatkan pemakaian majas dalam bentuk kata.

(1) Kepada Media seusai jumpa pers kemarin, Utut yang telah menekuni olahraga otak ini sejak 10 tahun mengaku merasa optimis bisa memenangkan wditarung tersebut.

(2) Jika di grup K Persib Bandung sudah memastikan diri maju ke semifinal delapan besar Divisi Utama Perserikatan PSSI, maka di Grup L masih terjadi ketegangan untuk menentukan siapa yang berhak meraih tiket keempat besar.

(3) Persija menurunkan algojo Patar Tambunan, Iskandar, Rahmad Darmawan, Toni Tanamal, dan Maman Suryaman.

(4) Taji PSM Ujung Pandang masih cukup tajam. 
Kata otak, tiket, algojo, dan taji dalam kalimat tersebut adalah kelompok kata dasar yang mengandung majas metafora di dalam konteks kalimatnya. Majas tersebut berkategori sebagai nomina. Di samping mengandung makna majasi, nomina-nomina tersebut juga mengandung fitur-fitur semantik yang merupakan ciri kodrati yang dikandungnya (Alwi, et al., 1993: 240).

Ditinjau dari sudut makna harfiah, otak adalah organ tubuh manusia yang merupakan alat untuk berpikir (KBBI, 2008: 709). Karena adanya persamaan sifat (berpikir), kata otak digunakan sebagai gambaran langsung untuk mengacu kepada olahraga yang memerlukan pemikiran.

Kata tiket bermakna 'karcis kapal' (KBBI, 2008: 1054). Di dalam konteks kalimat di atas, kata tiket dimanfaatkan sebagai perbandingan langsung untuk menggambarkan kemenangan yang diperebutkan dalam pertandingan. Kemudian, KBBI (2008: 25) mencantumkan kata algojo dengan makna 'orang yang melaksanakan hukuman mati'. Dalam pertandingan sepak bola, kata algojo digunakan untuk menggambarkan seorang pemain Persija yang berprestasi untuk timnya di dalam mencetak gol.

Selanjutnya, kata taji bermakna 'bagian yang runcing pada kaki ayam'. Penggunaan kata taji dalam konteks pemberitaan olahraga tersebut mengacu kepada makna 'kekuatan yang dimiliki oleh pemain Persib'.

Uraian tersebut membuktikan bahwa di dalam konteks kalimatnya, fitur-fitur semantik suatu kata atau nomina itu berubah dan mengandung makna sesuai dengan konteks kalimatnya. Ciri-ciri kodrati suatu benda digunakan sebagai analogi untuk melakukan perbandingan langsung antara pokok pertama yang merupakan hal-hal yang bersifat kodrati dengan pokok kedua yang merupakan hal-hal di luar sifat kodrati. Pada bagian ini jelas tejadi adanya penyimpangan makna. Oleh karena itu, bentuk kata yang mengandung makna majasi tersebut termasuk majas metafora.

Masih dengan majas metafora yang bentuk kata, berikut ini adalah contoh majas metafora dengan bentuk kata yang mendapat imbuhan ber-.

(1) Motivasi pemain Persib bertempur di lapangan lebih didorong oleh semangat Bandung lautan api.

(2) Ketidakberesan kondisinya itu diketahui setelah ia melakukan pemeriksaan cedera bahu kirinya usai berjibaku

(3) Hampir tidak pernah terlihat kedua penyeang Persib ini bebas beroperasi di jantung pertahanan Persija.

(4) Di final nanti kesebelasan Italia bertempur melawan kesebelasan Brasil.

Keempat kalimat di atas masing-masing mengandung kata bertempur, berjibaku, beroperasi, dan bertempur. Keempat kata tersebut adalah kata-kata yang mengandung makna majasi dalam konteks kalimat dan dapat dikategorikan sebagai verba. Pembentuk kata majasi tersebut berasal dari kata dasar tempur, jibaku, dan operasi, yang masingmasing mendapat tambahan afik ber-. Verba-verba tersebut menyatakan suatu perbuatan yang dilakukan oleh subjek. Jadi, secara semantis, verba tersebut mengandung makna inheren perbuatan (Alwi, et al. 2008: 93).

Di dalam KBBI (2008: 1035), kata bertempur mempunyai makna 'berlaga, berjuang'. Pada umumnya, kata tersebut digunakan dalam konteks kalimat yang mengandung makna 'perang'. Pihak lawan satu menghadapi pihak lawan yang lain. Kemudian, kata berjibaku digunakan dalam konteks kalimat yang mempunyai makna 'menyerang musuh dengan jalan menubrukkan dirinya pada musuh' (KBBI, 2008: 414). Kata beroperasi digunakan dalam kalimat yang mempunyai makna 'membedah', melakukan aktivitas kerja $(K B B I, 2008: 704)$. Dalam paparan tersebut sudah terlihat 
adanya konsep umum tentang kata bertempur dan beroperasi yang mengandung makna majasi.

Sesuai dengan konteks kalimatnya, (Keraf, 1991: 139), makna kata harfiah tersebut berubah menjadi makan denotasi. Kata berjibaku dalam kalimat tersebut digunakan untuk mendeskripsikan seorang atlet yang kalah dalam suatu pertandingan. Kata bertempur di dalam kalimat tersebut digunakan untuk mendeskripsikan suatu pertandingan bola, kata beroperasi menggambarkan perbuatan yang dilakukan oleh atlet Persib.

Berdasarkan uraian tersebut terlihat bahwa penyimpangan makna telah terjadi di dalam kalimat. Penyimpangan makna dalam konteks kalimat tersebut dimanfaatkan untuk melukiskan perbuatan yang dilakukan oleh pemain Persib yang dilukiskan akan 'bertempur' di lapangan.

Berikut ini masih berkaitan tentang pemakaian majas metafora dalam bentuk kata berimbuhan. Temuan majas tersebut termasuk ke dalam kelas verba pasif. Contoh majas metafora yang dimaksudkan tersebut adalah sebagai berikut.

(1) Pertama kali usulan itu digelindingkan oleh ketua federasi sepak bola dunia (FIFA)

(2) Dalam pertandingan ahad lalu di Hanover, Jerman, kesebelasan tuan rumah dibantai 0-2 oleh tamunya, Republik Irlandia.

(3) Dalam pertandingan persahabatan itu timnas Cina dicukur Korea Selatan dengan angka telak 3-0.

(4) Tiba-tiba Maradona mendekap kepalanya dengan kedua tangannya, saat gawang Argentina dirobek oleh striker Rumania,

Contoh kalimat di atas memperlihatkan adanya majas metafora yang ditemukan dalam bentuk pasif. Verba majasi tersebut adalah: digelinding, dibantai, dicukur, dan dirobek. Keempat kata tersebut mengandung makna majasi dalam konteks kalimat dan dapat dikategorikan sebagai verba. Pembentukan kata majasi tersebut berasal dari kata dasar gelinding, bantai, cukur, dan robek yang masing-masing mendapat tambahan afiks $d i$. Verba-verba tersebut menyatakan suatu perbuatan yang dilakukan oleh subjek. Jadi, secara semantis, verba tersebut mengandung makna inheren perbuatan (Alwi, et al. 2008:93).

Makna harfiah atau denotasi yang disandang kata dasar gelinding adalah 'berguling-guling seperti roda' (KBBI, 2008:303), kata bantai bermakna 'sembelih' (KBBI, 2008:91); kata cukur bermakna 'membersihkan janggut dengan pisau' (KBBI, 2008:198); kata robek bermakna 'terputus dari jahitan' (KBBI, 2008:844). Paparan tersebut memperlihatkan bahwa sudah ada konsep umum tentang verba- verba tersebut.

Dalam konteks kalimatnya, keempat kata majasi dalam bentuk pasif tersebut juga memanfaatkan kosakata yang sudah menjadi konsep umum itu untuk menggambarkan peristiwa-peristiwa dalam berita olahraga. Sesuai dengan konteks kalimatnya, makna kata-kata tersebut di atas berubah. Kata digelindingkan dapat diinterpretasikan menjadi makna 'dikeluarkan', kata ditelan dapat diinterpretasikan menjadi makna 'dialami'; kata dicukur dapat diinterpretasikan menjadi makna 'dikalahkan'; kata dirobek dapat diinterpretasikan menjadi makna 'kemasukan gol'. Dari paparan makna tersebut, jelas terasa bahwa perbandingan langsung yang dinyatakan dalam majas metafora tersebut dimanfaatkan untuk menggambarkan keadaan subjek yang dikenai tindakan oleh verba.

Masih berkisar tentang pemakaian majas metafora dalam bentuk kata berimbuhan, temuan berikut ini memperlihatkan majas metafora yang dibentuk dari kata dasar dengan tambahan afiks me-. Berikut di bawah ini majas metafora yang dimaksudkan tersebut. 
(1) Dengan hasil ini, tim putri. nasional mengantongi angka empat hasil dua kali menang.

(2) Upaya Persija mampu menumpulkan serangan Persib.

(3) Namun, perwujudan impian yang tinggal selangkah itu buyar ketika Jerman menumbangkan mereka di grand final itu dengan skor 0-1.

(4) Sebelumnya, atlet Indonesia itu melenggang ke final setelah menundukkan kandidat pemain terbaik Cina dengan skor 15-9, 17-18, dan 15-7.

(5) Timnas Wales menggilas pemain tuan rumah dalam pertandingan persahabatan.

(6) Kemenangan Persib itu mengubur harapan Persija yang telah lama merindukan gelar terhormat itu.

(7) Sejak menjadi juara dunia kelas berat, petinju itu sudah mengeruk uang sebesar US\$150 juta.

Data tersebut di atas memperlihatkan bahwa tujuh kalimat di atas masing-masing mengandung kata mengantongi, menumpulkan, menumbangkan, melenggang, menundukkan, menggilas, mengubur, merindukan, mengeruk. Kesembilan kata tersebut adalah kelompok kata berimbuhan yang mengandung makna majasi menurut konteks kalimatnya. Majas tersebut berkategori sebagai verba. Secara semantik, verba-verba itu bermakna inheren perbuatan (Alwi et al., 2008: 93) karena verba-verba aktif tersebut dapat menjadi jawaban atas pertanyaan apa yang dilakukan oleh subjek.

Ditinjau dari sudut makna denotatif, kata mengantongi bermakna 'memasukkan sesuatu ke dalam kantong (KBBI, 2008: 442), kata menumpulkan bermakna menjadikan tumpul (KBBI, 2008: 1083). Kemudian, kata menumbangkan bermakna 'merobohkan'(KBBI, 2008: 1080); kata melenggang bermakna 'berayun tangan' (KBBI, 2008:583), kata menundukkan bermakna 'menundukkan kepala' (KBBI, 2008:1084); kata menggilas bermakna 'menindih sambil menindas (KBBI, 2008:318), kata mengubur bermakna 'memakamkan' (KBBI, 2008: 535), kata merindukan bermakna 'sangat menginginkan atau mengharapkan' (KBBI, 2008: 842), kata mengeruk bermakna 'menggaruk dengan tangan' (KBBI, 2008: 491). Di dalam konteks kalimatnya, makna tersebut berubah menjadi makna konotasi (Keraf, 1993: 139).

Dengan melakukan perbandingan antara konsep umum yang mengandung makna harfiah dan kejadian-kejadian di dalam olahraga, dalam konteks kalimat kata mengantangi dapat diinterpretasikan menjadi makna 'menang atau memperoleh'; kata menundukkan, menumpulkan, menggilas, dan menumbangkan dapat diinterpretasikan menjadi makna 'mengalahkan'; kata melengggang dapat bermakna 'maju'. Penyimpangan makna dalam kalimat di atas juga membuktikan bahwa perubahan makna yang terjadi dimanfaatkan untuk melukiskan suatu kejadian dalam olahraga.

Pada bagian ini dibahas pemakaian majas metafora yang ditemukan dalam bentuk frasa, seperti terlihat di bawah ini

(1) Serangan balik PSM vs permainan cantik Persib.

(2) Belum lama ini muncul gagasan yang ditujukan ke PSSI untuk menyelenggarakan Kongres Luar Biasa (KLB), berurun rembuk untuk meluruskan kembali benang kusut.

(3) Namun, serangan-serangan yang dibangun Parma, acapkali menemui batu karang karena selalu ditujukan kepada stiker berkulit hitam asal Kolombia.

Data tesebut memperlihatkan bahwa kelompok kata permainan cantik Persib, benang kusut, dan batu karang merupakan frasa yang membentuk suatu majas metafora. Majas tersebut berkategori sebagai frasa nominal. 
Dari sudut harfiah, frasa nominal majasi tersebut mempunyai fitur-fitur semantik yang secara kodrati melekat pada kata yang membentuk suatu frasa (Alwi et al.,1993: 240). Di dalam konteks kalimatnya, ciri-ciri kodrati suatu kata ditandai oleh fitur-fitur semantik tersebut akan berubah. Makna harfiah atau denotasi yang disandang oleh kata tersebut berubah menjadi makna konotasi.

Paparan tersebut membuktikan bahwa frasa majasi tersebut digunakan sebagai perbandingan langsung untuk menggambarkan situasi atau keadaan yang dihadapi oleh subjek. Di dalam konteks kalimatnya, kata permainan cantik Persib digunakan untuk menggambarkan permainan atau pertandingan olahraga yang baik. Kemudian, frasa benang kusut digunakan untuk menggambarkan masalah yang rumit. Sementara itu, frasa batu karang digunakan untuk menggambarkan halangan yang dihadapi oleh subjek.

Selanjutnya, data berikut ini memperlihatkan pemakaian majas yang ditemukan dalam bentuk klausa, seperti terlihat berikut ini.

(1) Evander Holyfield akhdirnya gantung sarung tinju setelah dokter memastikan bahwa ia menderita gangguan jantung.

(2) Delapan menit pertandingan dimulai, Luis Calix menjebol gawang Brazil yang dijaga Taffarel dengan sundulan kepala.

(3) Selain ketiga gol itu sebenarnya Belgia yang di AS bergantung dengan Maroko, Belanda, dan Arab Saudi di grup F, masih mempunyai sejumlah peluang emas. Namun, gagal merobek gawang Hungaria.

Kalimat di atas mengandung kelompok kata yang merupakan bentuk klausa. Kata gantung dalam klausa gantung sarung tinju, kata menjebol dalam klausa menjebol gawang, kata merobek dalam klausa merobek gawang berfungsi sebagai pengisi kategori verba dalam majas yang berbentuk klausa tersebut. Dengan demikian, kelompok kata yang tercetak miring adalah klausa majasi.

Secara semantis, verba majasi tersebut mengandung makna inheren perbuatan (Alwi et al. 1993: 93), yaitu makna verba yang menyatakan apa yang dilakukan oleh subjek. Jika ditinjau dari sudut harfiah, verba perbuatan gantung itu bermakna 'sangkut, kait' (KBBI, 2008: 292), verba perbuatan menjebol bermakna 'merusak sampai terbongkar' (KBBI, 2008: 406); verba perbuatan merobek bermakna 'mengoyak' (KBBI, 2008: 844).

Makna-makna harfiah atau makna denotasi dari verba-verba tersebut akan berubah menjadi makna konotasi sesuai dengan konteks kalimatnya (Keraf, 1991:139). Pemahaman terhadap makna baru tersebut membutuhkan adanya kemampuan daya imajinasi dan pengembangan interpretasi sendiri dari seseorang (Moeliono, 1989: 175). Dengan demikian, secara relative makna dari frasa gantung sarung tinju, menjebol gawang, dan merobek gawang dapat berpadanan dengan makna 'memasukkan gol'. Sementara itu, gantung sarung tinju dapat berpadanan dengan makna 'mengundurkan diri atau keluar'.

Berdasarkan paparan tersebut, penyimpanan makna yang ditandai oleh perubahan makna dimanfaatkan untuk melukiskan kegiatan atau keadaan atlet dalam berita olahraga. Dengan kata lain, berita olahraga memanfaatkan pemakaian majas di dalam menyajikan informasinya.

\section{KESIMPULAN}

Bahasa Indonesia ragam jurnalistik banyak diwarnai oleh pemakaian majas terutama dalam bidang olahraga. Salah satu temuan majas itu adalah majas metafora. Majas metafora yang ditemukan dalam pemberitaan surat kabar itu berupa kata, frasa, dan klausa. Pada umumnya, majas-majas tersebut mengandung perbandingan antara objek 
yang mempunyai makna murni, makna yang sesuai dengan ciri-ciri kodrati suatu kata dan hal yang mengacu pada objek yang mempunyai makna lain di luar ciri-ciri kodrati tersebut.

Dalam pemberitaan di bidang olahraga, frekuensi pemakaian majas lebih tinggi jika dibandingkan dengan nonbidang olahraga. Di samping itu, bentuk-bentuk majas di bidang olahraga lebih bersifat kreatif. Kreasi majas tersebut banyak ditemukan dalam dalam jenis majas metafora. Misalnya, untuk mengungkapkan maksud bola masuk ke dalam gawang lawan dipakai kiasan dalam bentuk majas, seperti: menjebol gawang, merobek gawang, dan membobol gawang.

Selanjutnya, seorang atlet atau pemain yang berhasil memasukkan bola juga dikiaskan dengan majas metafora, seperti penjebol gawang, pembunuh, algojo, dan pembobol gawang. Kemudian, di akhir pertandingan jika suatu tim memperoleh kemenangan akan dikiaskan dengan majas metafora juga, seperti melibas, menaklukkan, memetik, kemenangan, meraih tiket ke per empat final, merontokkan, menundukkan, dan membunuh. 


\section{DAFTAR PUSTAKA}

Alwi, Hasan. 1992. Seri Penyuluhan 3. Bentuk dan Pilihan Kata. Jakarta: Pusat Pembinaan dan Pengembangan Bahasa, Departemen Pendidikan dan Kebudayaan.

2008. Tata Bahasa Baku Bahasa Indonesia. Jakarta: Departemen Pendidikan dan Kebudayaan..

Aminuddin. 1998. Semantik: Pengantar Studi tentang Makna. Bandung: CV Sinar Baru.

Departemen Pendidikan dan Kebudayaan. 2008. Kamus Besar Bahasa Indonesia. Jakarta: Balai Pustaka.

Djajasudarma, T. Fatimah. 1994. Semantik 2: Pemahaman Ilmu Makna. Bandung:PT Eresco.

Ensiklopedi Nasional Indonesia. 1990. Jilid 10. Jakarta: PT Cipta Adi Pustaka.

Keraf, Gorys. 1991. Diksi dan Gaya Bahasa: Komposisi Lanjutan I. Ende: Nusa Indah.

Kridalaksana, Harimurti. 2008. Kamus Linguistik. Jakarta: PT Gramedia Pustaka Utama.

Lumintaintang, Yayah B. 1992. "Permasalahan Kebahasaan di dalam Ragam Bahasa Media Massa Cetak” dalam Bahasa dan Sastra. Th.IX No.6. 1992. Jakarta: Pusat Pembinaan dan Pengembangan Bahasa.

Moeliono, Anton M. 1989. Kembara Bahasa Kumpulan Karangan Tersebar. Jakarta: Gramedia.

Pateda, Mansoer. 2010. Semantik Leksikal. Jakarta: Rineka Cipta.

Sudaryanto. 1986. Metode Linguistik: Ke Arah Memahami Metode Linguistik. Yogyakarta: Gajah Mada University Press. 